\title{
African Generation Y Male Students' Fashion Consciousness Behaviour
}

\author{
Matebello D.B. Motale \\ Vaal University of Technology (Vanderbijlpark Campus) \\ Email: matebellom@vut.ac.za \\ Ayesha L. Bevan-Dye \\ North-West University (Vaal Triangle Campus) \\ Email: ayeshabevandye@gmail.com or Ayesha.Bevandye@nwu.ac.za \\ Natasha de Klerk PhD. \\ North West University (Vaal Triangle Campus) \\ Email: Natasha.deKlerk@nwu.ac.za
}

\section{Doi:10.5901/mjss.2014.v5n21p121}

\begin{abstract}
While there have been numerous studies directed at addressing the female Generation $Y$ cohort's fashion consumption patterns, there is a dearth of published research focused on male consumer fashion conscious behaviour, especially not that of the African Generation Y (hereafter referred to as African Generation Y) males. Born between 1986 and 2005, in 2013, African Generation Y individuals made up approximately 83 percent of South Africa's total Generation Y cohort and 38 percent of the country's 52981991 population in 2013. The aim of this study was to determine the causal relationships between African Generation Y male students' need for fashion awareness, fashion consciousness and fashion conscious behaviour. A selfadministered questionnaire was administered on a single cross-sectional sample of 400 African Generation Y male students at three university campuses in the Gauteng province. The data was analysed by means of exploratory factor analysis, correlation and regression analysis. The findings suggest that African Generation Y males' fashion awareness and fashion consciousness has a significant postive influence on their fashion conscious behaviour.
\end{abstract}

Keywords: Male fashion awareness; male fashion consciousness; male fashion conscious behaviour; Generation Y

\section{Introduction}

Whilst fashion consumption has traditionally been considered as being more of a female pursuit (Rathnayake, 2011), there is growing evidence that their male counterparts are showing a marked increase in their fashion awareness and fashion consciousness (Bakewell, Mitchell \& Rothwell, 2006; Rathnayake, 2011). Nam, Hamlin, Gam, Kang, Kim, Kumphai, Starr and Richards (2006:103) define fashion consciousness as "a person's degree of involvement with the styles or fashion of clothing". Factors thought to have contributed to the increase in male fashion consciousness include gender role fragmentation, the use of celebrity sportsmen as fashion models, and the increased popularity of men's fashion magazines that promote the concept of the metro-sexual new man (Bakewell et al., 2006). A study conducted on the Eastern European markets revealed that young males were in fact more fashion conscious than their female counterparts were (Manrai, Lascu, Manrai \& Bubb, 2001). In South Africa, the compound annual growth rate in the menswear market between 2004 and 2008 amounted to 7.8 percent in comparison to the growth rate in womenswear that amounted to 9.2 percent (Research and Markets, 2010). This suggests that men are becoming increasingly more fashion aware and fashion conscious and, consequently, engage more in fashion conscious behaviour.

The youth market offers an important target market for fashion and apparel marketers (Cassidy \& Van Schijndel, 2011). In marketing speak, the youth market of the twenty-first century is labelled Generation Y. Born between 1986 and 2005 (Markert, 2004), Generation Y (also known as echo boomers and the millennium generation) are the children of baby boomers (Martin, 2005) or Generation X (Herbig, Koehler \& Day, 1993). Working within the confines of South Africa's mid-year population count categories, Generation $Y$ members made up approximately 38 percent of South Africa's population of 52981991 in 2013. The African portion of South Africa's Generation Y cohort (hereafter referred to as African Generation Y) amounted to a significant 83 percent. The African Generation $Y$ male segment accounts for 
41.90 percent of South Africa's total Generation Y cohort, and 50.24 percent of the African Generation Y cohort (Statistics South Africa, 2013a). The size of this age and gender cohort translates into it representing an attractive market segment for marketers. Members of the African male Generation $Y$ cohort, who have a tertiary qualification, are of special relevance to marketers, given that a higher education often predicts a higher future earning potential and a higher social standing (Bevan-Dye, Dhurup \& Surujlal, 2009), which, in turn, predicts a higher level of consumption and opinion leadership within a given cohort.

While numerous studies focusing on female Generation $Y$ members and older Generation $Y$ members have been conducted internationally, with particular emphasis on their fashion consumption patterns (Hogg, Bruce \& Hill, 1998; O'Cass \& Choy, 2008; Bakewell \& Mitchell, 2003; Martin \& Turley, 2004; Rahman \& Azhar, 2011), there is a lack of published literature on male fashion consumption patterns, especially African Generation Y males' fashion consumption. To date, few academic studies regarding the consumer behaviour of the African Generation $Y$ members have been undertaken in South Africa, and none that focus specifically on the male African Generation Y segment of the cohort. Despite African Generation Y males representing a lucrative marketing opportunity for apparel retailers and fashion marketers in South Africa, there is a dearth of published studies in this area. There is need to gain insight into the consumer behaviour of this segment in terms of their fashion awareness, fashion consciousness and fashion conscious behaviour in order to tailor the marketing strategies employed to target this segment. As those with a tertiary qualification are expected to have a higher earning potential and, consequently, a higher consumption potential and social influence, an understanding of the student portion of this cohort is likely to offer particularly valuable insight into the fashion conscious behaviour of African Generation Y males in South Africa.

As such, the primary purpose of this study was to determine the causal relationships between African Generation $Y$ male students' fashion awareness, fashion consciousness and fashion conscious behaviour.

\section{South African Fashion Industry}

Since 1994, South Africa has spent an estimated US\$1 billion on modernising the country's textile, clothing and footwear industry in a bid to help this sector to compete more efficiently in the global arena (SouthAfrica.info, 2009). The literature reveals that the combined effects of globalisation and trade liberation have influenced the South African fashion apparel industry strongly (Kaplan, 2004; Rogerson, 2006). Whereas the South African fashion apparel industry once was protected from international competition, the 1994 democratic elections saw the country joining the World Trade Organisation and a period of substantial trade liberalisation, which resulted in the local apparel industry competing against a surge of foreign imports, particularly from China (Vlok, 2006). Although the struggle to compete against low-cost Chinese apparel imports remains an issue in both South Africa (Phakathi, 2013) and Africa as a whole (Corcoran, 2013), the country experienced a strong growth in apparel sales volumes in 2012 (Euromonitor International, 2013).

In 2012, retailers in textiles, clothing, footwear, and leather goods contributed an estimated 18 percent to the country's total retail trade sales, second only to general dealers (Statistics South Africa, 2013b). South Africa's fashion industry is the fifth largest sector in the country and generates an income of several billion Rand annually (Fashion Web, 2013). Furthermore, according to a study conducted by Grail Research (2009), Johannesburg, the capital city of Gauteng in South Africa, has emerged as the "Fashion District" and top global fashion capital in Africa.

In South Africa, the retail apparel industry is dominated by a limited number of strong national retailers such as the Edcon Group that includes the Jet and Edgars chain, Truworths, Mr Price, Pepkor, Woolworths (Euromonitor International, 2013) and the Foschini Group (PwC, 2012). In 2012, the South African retail industry contributed an estimated US\$8.9 billion to the economy, which equates to an estimated 6.4 percent compound annual growth rate between 2008 and 2012 (MarketLine, 2013). Much of the forecasted growth in South Africa's apparel retail sales is expected to come from upper-income Generation $Y$ males who are embracing purchasing high-end premium clothing brands as a signal of their financial and social upward mobility (Euromonitor International, 2013).

\section{Fashion Conscious Behaviour}

In the context of this study, male fashion conscious behaviour is contextualised as the extent to which men engage in the activity of fashion shopping, purchase the latest styles, shop at trendy fashion outlets, keep up with fashion news via mass media such as fashion magazines, and take care in how they assemble fashion items. According to Bakewell et al. (2006), fashion conscious behaviour manifests as the motivation to consume fashion.

This concept of fashion conscious behaviour relates to enduring product involvement, which, according to Richins and Bloch (1986), refers to an individual's long-term attachment to a particular product class, such as fashion apparel, 
and typically manifests as extensive information search and brand knowledge that is independent of the specific purchase situation. Bertrandias and Goldsmith (2006) assert that individuals with an enduring product involvement exhibit an interest in that product class regardless of whether they anticipate making a purchase. This suggests that the activities of reading fashion magazines and shopping at trendy stores relate to enduring fashion involvement.

In terms of actual purchase behaviour, there has been a marked increase in the purchase of fashion menswear, which is forecasted to exceed US\$ billion in 2014 (Attire Club, 2013). In South Africa, young upper-income males who perceive premium fashion apparel brands as indicators of their financial and social success are expected to drive the demand for fashion menswear (Euromonitor International, 2013). Many of these are likely to be African Generation $Y$ male students who, owing to the higher potential earning power and higher social standing, typically afforded by a tertiary qualification, are either current Black Diamonds or likely future Black Diamonds (Bevan-Dye, 2013).

Male fashion conscious behaviour presupposes a level of fashion awareness and fashion consciousness.

\section{Fashion Awareness and Fashion Consciousness}

While fashion awareness and fashion consciousness typically are used interchangeably in the literature, there is a subtle difference between the two concepts. The COED (2004:91) defines awareness as "having knowledge or perception of a situation or fact." According to LaBerg (1998), "the experience of attending to an object becomes an experience of being aware of that object." In the context of this study, male fashion awareness is contextualised as the extent to which men perceive some fashion apparel as being more fashionable than that of others and, indeed, some men as being more fashionable than others are. For the purpose of this study, fashion awareness is defined as the level of attention an individual pays to fashion. Furthermore, the study makes the reasonable assumption that male fashion awareness is a necessary condition for male fashion consciousness.

Fashion consciousness, in contrast, relates to consumer ego involvement, which Michaelidou and Dibb (2008) describe as including the elements of centrality, commitment and importance. Manrai et al. (2001) define fashion consciousness as an individual's involvement and attention to the latest fashion trends. Gutman and Mills (1982) describe fashion consciousness as having an interest in fashion, believing the importance of being fashionable, having the desire to be well-dressed, and being a fashion leader. Sproles and Kendell (1986) indicate that being in style and keeping up to date with the latest fashion trends are important characteristics of the fashion-conscious consumer.

According to Gould and Stern (1989), fashion conscious males tend to relate fashion apparel to their self-identity and their concept of what being a man means. In the context of this study, male fashion consciousness is conceptualised as being alert to changes in fashion, perceiving oneself as being fashionable and being perceived by others as being fashionable.

\section{Research Methodology}

\subsection{Sample}

The sampling frame for this study consisted of African Generation Y male students enrolled at South African public higher education institutions (HEls) located in the Gauteng Province. The reason for selecting this geographic area is that the Gauteng province comprises the largest share of the South African population. Approximately 12.7 million people (24 percent) live in this province (Statistics South Africa, 2013a). Specifically, three university campuses formed part of the sampling frame - one from a comprehensive university, one from a university of technology, and one from a traditional university. The reason for selecting these institutions was their high student enrolment figures and their ratio of African male students as compared to other HEIs (Council on Higher Education and Higher Education Quality Committee, 2012).

A non-probability convenience sample of 400 African Generation $Y$ male students enrolled at the three respective South African institutions was drawn for the final study. Questionnaires were distributed evenly at the respective university campuses. Lecturers employed at each of the three HEI campuses were contacted and asked if they would allow a self-administered questionnaire to be distributed to their students during lectures. Once permission was gained, a structured self-administered questionnaire was administered during scheduled lectures by the study researcher. Participation in the survey was strictly on a voluntary basis.

\subsection{Research instrument}

For the empirical portion of the study, two revised scales were adapted to suit the objectives for this study. Gould and 
Stern (1989) developed the first scale used to measure fashion consciousness and Rukandema (2000) revised it to make it specifically applicable to men's fashion consumption and relevant to the 1990s. Bakewell et al. (2006) used an adapted version of the Rukandema (2000) scale to measure male fashion consciousness in the United Kingdom (UK) market. For this study, items from the Bakewell et al. (2006) scale were selected to reflect the dimensions of male fashion awareness (four items), fashion consciousness (six items) and fashion conscious behaviour (five items). Responses to scaled items were measured using a six-point Likert scale (1=strongly disagree to $6=$ strongly agree). In addition, the questionnaire included a section designed to elicit demographic information, and a cover letter indicating the purpose for the study and providing the necessary contact details.

In order to ensure the reliability of the questionnaire in the South African context, the questionnaire was pilot tested at a $\mathrm{HEI}$ campus not included in the sampling frame. For the pilot, 40 African Generation Y male students were requested to take part in the survey on a voluntary basis. The Cronbach alpha values computed for the pilot test all exceeded the recommended level of 0.700 (Pallant, 2010) and ranged between 0.710 and 0.844 for the three dimensions of male fashion consciousness, thereby indicating acceptable internal reliability.

\section{Results}

\subsection{Sample description}

Of the 400 questionnaires administered, participants completed and returned 213 usable questionnaires. As illustrated in Table 1, participant's ages ranged between 18 to 24 years. Furthermore, findings revealed that of South Africa's nine provinces, the majority of the participants were from Gauteng (53.8\%), followed by Free State (11.1\%), and Limpopo and North West with (10.1\%) respectively. There were no participants from the Western Cape.

Table 1: Sample description

\begin{tabular}{cclclc}
\hline Age & Percent (\%) & Province & Percent (\%) & HEI & Percent (\%) \\
\hline 18 & 15.5 & Eastern Cape & 4.8 & Traditional University & 41.3 \\
19 & 19.9 & Free State & 11.1 & Comprehensive University & 19.7 \\
20 & 18.4 & Gauteng & 53.8 & University of Technology & 39.0 \\
21 & 18.0 & KwaZulu-Natal & 3.4 & & \\
22 & 14.6 & Limpopo & 10.1 & & \\
23 & 9.7 & Mpumalanga & 6.3 & & \\
24 & 3.9 & Northern Cape & 0.5 & & \\
& & North West & 10.1 & & \\
& & Western Cape & 0 & & \\
\hline
\end{tabular}

\subsection{Exploratory factor analysis}

Exploratory factor analysis (EFA) was performed on all the construct-related items. Prior to undertaking the EFA, the Kaiser-Meyer-Olkin (KMO) measure of sampling adequacy and the Bartlett Test of Sphericity were executed. Research indicates that a KMO value above 0.6 and a significant Bartlett's Test of Sphericity value are generally favoured (Pallant, 2010). The two tests yielded satisfactory results for the male fashion consciousness scale (KMO $=0.873$, chi-square Bartlett test $=1490.343(\mathrm{df}=120), \mathrm{p}=0.000<0.05)$. Thereafter, principal component factor analysis using varimax rotation was carried out. Table 2 outlines the rotated factor loading, communalities, eigenvalues, variance explained and reliability coefficients for the male fashion consciousness scale. 
Table 2. Principle component factor analysis with promax rotation

\begin{tabular}{|c|c|c|c|c|}
\hline \multirow{2}{*}{ Male fashion consciousness items } & \multicolumn{3}{|c|}{ Factor loadings } & \multirow{2}{*}{ Communalities } \\
\hline & 1 & 2 & 3 & \\
\hline \multicolumn{5}{|l|}{ Fashion awareness } \\
\hline I am aware that some shirts are more fashionable than others & & & .810 & .717 \\
\hline I am very aware that some shoe styles are more fashionable than others & & & .821 & .716 \\
\hline I am very aware that some clothes for men are more fashionable than others & & & .881 & .811 \\
\hline I usually notice that some men are more fashionable & & & .661 & .463 \\
\hline \multicolumn{5}{|l|}{ Fashion consciousness } \\
\hline I am very alert to changes in men's fashion/trends & .547 & & & .423 \\
\hline I am more fashionable/style conscious than the average man & .757 & & & .676 \\
\hline I would say I am very fashion conscious & .750 & & & .657 \\
\hline Other people think I am fashionable/trendy & .669 & & & .528 \\
\hline I know which type of men's clothes are fashionable & .665 & & & .558 \\
\hline I think I am fashionable/trendy & .809 & & & .708 \\
\hline \multicolumn{5}{|l|}{ Fashion conscious behaviour } \\
\hline I take a long time to decide about the clothes I wear & & .668 & & .513 \\
\hline I usually shop in trendy stores & & .528 & & .406 \\
\hline I read magazines that have fashion/style pages & & .700 & & .529 \\
\hline I am always shopping for new clothes & & .629 & & .532 \\
\hline Other people ask me what is fashionable/trendy & & .570 & & .507 \\
\hline I am usually the first to buy the latest styles & & .703 & & 606 \\
\hline Eigenvalues & 6.15 & 1.99 & 1.22 & \\
\hline Variance explained & 38.15 & 12.42 & 7.60 & \\
\hline Reliability coefficient & 0.85 & 0.79 & 0.82 & \\
\hline
\end{tabular}

As is evident from Table 2, three factors emerged with eigenvalues above 1.00 and these three factors explained 58.44 percent of the total variance. All factor loadings were above 0.50 , indicating practical significance and all communalities are above 0.40 , with the majority being above 0.50 , which suggests that a large amount of the variance in an item has been extracted by the factor solution (Hair, Black, Babin \& Anderson, 2010). Furthermore, the Cronbach alpha values computed all exceeded the 0.70 level, which suggests high internal consistency. In order to assess the content validity of the instrument, the average inter-item correlation coefficient for the overall scale was computed. According to Clark and Watson (1995), an average inter-item correlation value that falls within the range of 0.15 and 0.50 is indicative of convergent and discriminant validity. The average inter-item correlation coefficient for this instrument was computed as 0.339 , thereby suggesting content validity.

\subsection{Correlation analysis}

Pearson's Product-Moment correlation analysis was then carried out to determine the relationships between male fashion awareness, fashion consciousness and fashion conscious behaviour. Table 3 reports the correlation matrix.

Table 3: Correlation matrix

\begin{tabular}{|c|c|c|c|}
\hline Constructs & 1 & 2 & 3 \\
\hline Fashion awareness & 1 & & \\
\hline Fashion consciousness & $0.411^{*}$ & 1 & \\
\hline Fashion conscious behaviour & $0.381^{*}$ & $0.611^{*}$ & 1 \\
\hline
\end{tabular}

According to the correlation coefficients reported on in Table 3, there is a significant positive relationship between fashion consciousness and fashion consciousness behaviour ( $r=6.11, p=0.000<0.05)$, between fashion awareness and fashion consciousness $(r=0.411, p=0.000<0.05)$, and between fashion awareness and fashion consciousness behaviour $(r=0.381, p=0.000<0.05)$. 


\subsection{Regression analysis}

Following the correlation analysis, regression analysis was conducted for the purpose of determining the influence of male fashion awareness and fashion consciousness on fashion consciousness behaviour. The results of this regression analysis are provided in Table 4.

Table 4: Regression analysis

\begin{tabular}{lcccc}
\hline & Standardised Beta & Adjusted R & t-value & Significance \\
\hline Dependent variable: & & & & \\
Fashion conscious behaviour & & & & \\
Independent variables: & 0.156 & 0.387 & 2.653 & $0.009^{*}$ \\
Fashion awareness & 0.546 & & 9.262 & $0.000^{*}$ \\
Fashion consciousness & & & & \\
\hline${ }^{*}$ Significant at the 0.05 level (2-tailed) & & &
\end{tabular}

As can be seen from Table 4 , while both fashion consciousness $(\beta=0.546, p=0.000<0.05)$ and fashion awareness $(\beta=0.156, p=0.009<0.05)$ have a significant positive influence on African Generation $Y$ male students' fashion conscious behaviour, fashion consciousness makes the strongest unique contribution to explaining male fashion conscious behaviour. The combined influence of fashion awareness and fashion consciousness explains approximately 40 percent of the variance in male fashion conscious behaviour.

\section{Discussion}

This study sought to determine the causal relationships between African Generation Y male students' fashion awareness, fashion consciousness and fashion conscious behaviour in the South African context. The instrument used in this study comprised the 16 items drawn from the male fashion conscious scale utilised by Bakewell et al. (2006). Exploratory factor analysis revealed a three-factor structure that exhibits strong internal consistency as well as content validity. As such, this scale provides a reliable and valid instrument for measuring male fashion consciousness along the three dimensions of male fashion awareness, fashion consciousness and fashion conscious behaviour. Whilst this scale was used to measure overall male fashion conscious behaviour, it can be adapted to measure specific male fashion conscious behaviour as they pertain to different male fashion sectors, such as male clothing, male fashion magazines, male cosmetics, male beauty treatments and the like.

The findings of this study suggest a strong relationship between male fashion awareness, fashion consciousness and fashion conscious behaviour, with fashion awareness and fashion consciousness having a significant positive influence on male fashion conscious behaviour. This suggests that if male fashion awareness and consciousness can be stimulated, male fashion conscious behaviour will result.

Marketing fashion to males should be approached differently from marketing fashion to females. At the heart of male fashion marketing is overcoming men's fears of being perceived as being effeminate. Marketing communication efforts should focus on conveying the message that appropriate referent others consider male fashion conscious behaviour to be both acceptable and desirable. The rise in the metro-sexual male is considered an important driver to male fashion conscious behaviour and celebrity endorsers, especially sports celebrities, are viewed as having played an important role in this regard. The use of local African celebrity male endorsers, particularly those who earned their celebrity status on the sports field, is likely to increase the acceptability and desirability of male fashion conscious behaviour. Marketers of male fashion products need to appeal to known male-specific motives such as occupational and financial success, physical strength, status and sexual proneness. Retail establishments selling male fashion products should also ensure that their decor and service personnel reflect a strong sense of masculinity.

\section{Limitations and Implication for Future Research}

While adequate measures were taken to ensure fair representation of the sample in line with the target population's demographic profile, the study made use of non-probability sampling, which means that care should be taken in generalising the results of the sample to the entire African Generation $Y$ male student cohort. In addition, even though graduates are expected to have a role model influence on the wider African Generation $Y$ male cohort, there is scope for 
a study that measures the need for uniqueness, fashion awareness, fashion consciousness and fashion conscious behaviour amongst non-students. Furthermore, while the sample in this study represented eight of South Africa's nine provinces, the study only focused on students enrolled at three HEls located within the Gauteng province. A study that draws a sample of male students from HEl campuses nationally may offer deeper insights into the need for uniqueness and fashion consciousness. This study also was confined to quantitative analysis, whereas a mixed-mode research design that incorporates qualitative data from focus groups and depth interviews may provide valuable insight into that research problem addressed in this study.

\section{Conclusion}

Fashion marketers who currently target, or who are planning to target, the African Generation Y male cohort in South Africa need to familiarise themselves with this market. This segment appears to use fashion clothing as an important way of signalling their self-image. In this regard, not only does it articulate their status but also serves as a form of selfexpression that allows them to distinguish themselves as individuals. In order to target African Generation $Y$ males successfully, fashion marketers need to stimulate fashion awareness and fashion consciousness, which, in turn, will lead to male fashion conscious behaviour.

\section{References}

Attire Club. (2013). Fashion industry statistics you probably did not know. Fashion world. September 28. [Online] Available: http://attireclub.org/2013/09/28/fashion-industry-statistics-you-probably-did-not-know/ (4 December 2013).

Bakewell, C. \& Mitchell, V.W. (2003). Generation Y female consumer-decision-making styles. Journal of Retail and Distribution Management, 31(2), 95-106.

Bakewell, C., Mitchell, V.W. \& Rothwell, M. (2006). UK generation Y male fashion consciousness. Journal of Fashion Marketing and Management, 10(2), 169-180.

Bertrandias, L. \& Goldsmith, R.E. (2006). Some psychological motivations for fashion opinion leadership and fashion opinion seeking. Journal of Fashion Marketing and Management, 10(1), 25-40.

Bevan-Dye, A.L. (2013). Black generation Y students' attitudes towards web advertising value. Mediterranean Journal of Social Sciences, 4(2), 155-164.

Bevan-Dye, A.L., Dhurup, M. \& Surujlal, J. (2009). Black generation Y students' perceptions of national sport celebrity endorsers as role models. African Journal for Physical Health Education, Recreation and Dance (Supplement), 172-188.

Cassidy, T.D. \& Van Schijndel, H. (2011). Youth identity ownership from a fashion marketing perspective. Journal of Fashion Marketing Management, 15(2), 163-177.

Clark, L.A. \& Watson, D. (1995). Construct validity: basic issues in objective scale development. Psychological Assessment, 7(3), 309319.

COED (Concise Oxford English Dictionary). (2004). (11th ed). Oxford: Oxford University Press.

Corcoran, B. (2013). Investment key to Africa's clothing industry growth. Just-Style.com. April 16. [Online] Available: http://www.juststyle.com/analysis/investment-key-to-africas-clothing-industry-growth_id117543.aspx (4 December 2013).

Council on Higher Education and Higher Education Quality Committee. (2012). Higher education in South Africa 2011. [Online] Available: http://www.che.ac.za/media_and_publications/monitoring-and-evaluation/higher-education-south-africa-data-2011 (17 November 2013).

Euromonitor International. (2013). Apparel in South Africa: executive summary. [Online] Available: http://www.euromonitor.com/apparelin-south-africa/report (27 November 2013).

Fashion Web. (2013). South African fashion. [Online] Available: http://www.fashionweb.co.za/south-africa (1 March 2013).

Gould, S.J. \& Stern, B.B. (1989). Gender schema and fashion consciousness. Psychology and Marketing, 6(2), 129-145.

Grail Research. (2009). The global fashion industry: growth in emerging markets. [Online] Available: http://www.grailresearch.com/pdf/ ContenPodsPdf/Global_Fashion_Industry_Growth_in_Emerging_Markets.pdf (2 February 2012).

Gutman, J. \& Mills, M.K. (1982). Fashion life style, self-concept, shopping orientation, and store patronage: an integrative analysis. Journal of Retailing, 58(2), 64-86.

Hair, J.F., Black, W.C., Babin, B.J. \& Anderson, R.E. (2010). Multivariate data analysis: a global perspective. (7th ed). Upper Saddle River, N.J.: Pearson.

Herbig, P., Koehler, W. \& Day, K. (1993). Marketing to the baby generation. Journal of Consumer Marketing, 10(1), 4-9.

Hogg, M.K., Bruce, M. \& Hill, A.J. (1998). Fashion brand preferences among young consumers. Journal of Retail and Distribution Management, 26(8), 293-300.

Kaplan, D. (2004). Manufacturing in South Africa over the last decade: a review of industrial performance and policy. Development Southern Africa, 21(4), 623-644.

LaBerg, D. (1998). Defining awareness by the triangular circuit of attention. Psyche, 4(7). [Online] Available: http://psyche.cs.monash. edu.au/v4/psyche-4-07-laberge.html (8 December 2013). 
Manrai, L.A., Lascu, D.N., Manrai, A.K. \& Bubb, H.W. (2001). A cross-cultural comparison of style in Eastern European emerging markets. International Marketing Review, 18(3), 270-285.

Markert, J. (2004). Demographics of age: generational and cohort confusion. Journal of Current Issues and Research in Advertising, 26(2), 12-25.

MarketLine. (2013). Apparel retail in South Africa. Marketresearch.com: February 27. [Online] Available: http://www.marketresearch.com/ MarketLine-v3883/Apparel-Retail-South-Africa-7677066/ (8 December 2013).

Martin, C.A. (2005). From high maintenance to high productivity: what managers need to know about Generation Y. Industrial and Commercial Training, 35(1), 39-44.

Martin, C.A. \& Turley, L.W. (2004). Malls and consumption motivations an exploratory examination of older generation $Y$ consumers. Journal of Retail and Distribution Management, 32(10), 464-475.

Michaelidou, N. \& Dibb, S. (2008). Consumer involvement: a new perspective. Marketing Review, 8(1), 83-99.

Nam, J., Hamlin, R., Gam, H.J., Kang, J.H., Kim, J., Kumphai, P., Starr, C. \& Richards, L. (2006). The fashion-conscious behaviours of mature female consumers. International Journal of Consumer Studies, 31(1), 102-108.

O'Cass, A. \& Choy, E. (2008). Studying Chinese Generation Y consumers' involvement in fashion clothing and perceived brand status. Journal of Product and Brand Management, 17(5), 341-352.

Pallant, J. (2010). SPSS survival manual: a step by step guide to data analysis using SPSS for Windows. (4th ed). New York: McGrawHill.

Phakathi, B. (2013). South African clothing sector set for rebound. Business Day Live. January 22. [Online] Available: http://www.bdlive.co.za/business/retail/2013/01/22/south-african-clothing-sector-set-for-rebound (8 December 2013).

PwC (PricewaterhouseCoopers). (2012). South African retail and consumer products outlook 2012-2016. [Online] Available: http://www.pwc.co.za/en_ZA/za/assets/pdf/retail-and-consumer-products-outlook-2012-2016.pdf (27 November 2013).

Rahman, S. \& Azhar, S. (2011). Xpressions of generation Y: perceptions of the mobile phone service industry in Pakistan. Journal of Marketing and Logistics, 23(1), 91-107.

Rathnayake, C.V. (2011). An empirical investigation of fashion consciousness of young fashion consumers in Sri Lanka. Young Consumers: Insight and Ideas for Responsible Marketers, 12(2), 121-132.

Research \& Markets. (2010). Clothing: South African industry guide 2010. [Online] Available: http://www.researchandmarkets. com/research/ee4545/clothingsouth_af (2 February 2012).

Richins, M.L. \& Bloch, P.H. (1986). After the new wears off: the temporal context of product involvement. Journal of Consumer Research, 3, 280-285.

Rogerson, C.M. (2006). Fashion and the growth of African brands in South Africa. African Clothing and Footwear Research Network. University of the Witwatersrand. South Africa. [Online] Available: http://www.repository.brandleadership.com/documents/ download/92ef5b88-2133-41b9-b937-30503c.17873f (18 November 2012).

Rukandema, T. (2000). Male fashion consciousness and magazine consumption. Manchester: UMIST. (Dissertation - MSc.).

SouthAfrica.info. (2009). South Africa's textile industry. November 13. [Online] Available: http://www.southafrica.info/business/economy/ sectors/textiles-overview.htm (21 October 2013).

Sproles, G.B. \& Kendall, E.L. (1986). A methodology for profiling consumer decision-making styles. Journal of Consumer Affairs, 20(2), 267-279.

Statistics South Africa. (2013a). Mid-year population estimates: 2013. Statistical release P0302. [Online] Available: http://www.statssa. gov.za/publications/P0302/P03022013.pdf (12 August 2013).

Statistics South Africa. (2013b). Retail trade sales (Preliminary), March. [Online] Available: http://www.statssa.gov.za/publications/ P62421/P62421March2013.pdf (13 November 2013).

Vlok, E. (2006). The textile and clothing industry in South Africa. (In Jauch, H \& Traub-Merz, R., eds. The future of the textile and clothing industry in Sub-Saharan Africa. Bonn: Friedrich-Ebert-Stiftung. p. 227-246.) [Online] Available: http://www.library.fes.de/ pdf-files/iez/03796/16suedafrola.pdf (16 September 2012). 